\title{
KARAKTERISTIK ASAS KEPENTINGAN (INSURABLE INTEREST) DALAM PERJANJIAN ASURANSI
}

\author{
Fitria Dewi Navisa \\ Fakultas Hukum \\ Universitas Islam Malang \\ Email : fd.navisa@yahoo.com
}

\begin{abstract}
Abstrak
Benda asuransi erat hubungannya dengan teori kepentingan (interest theory) yang secara umum dikenal dalam hukum asuransi. Kepentingan itu harus sudah ada pada benda asuransi pada saat asuransi diadakan atau setidak-tidaknya pada saat terjadi peristiwa yang menimbulkan kerugian (evenemen). Problematika yuridis dalam penelitian ini adalah belum adanya penjelasan terkait asas kepentingan dalam Undang-Undang No. 14 Tahun 2014 tentang Perasuransian (kekosongan norma), sehingga tidak terdapat standarisasi tentang asas kepentingan beserta karakteristiknya. Untuk menemukan jawaban atas permasalahan dalam penelitian ini, maka peneliti akan mempergunakan teori-teori hukum tertentu sebagai landasan untuk menganalisanya. Teori itu meliputi; Teori Perlindungan Hukum, Teori Kepastian Hukum, Teori Investasi, dan Teori Asuransi. Metode pendekatan yang digunakan adalah bersifat yuridis normatif. Penelitian ini menggunakan 4 macam pendekatan, yakni pendekatan perundang-undangan (statute approach), pendekatan konseptual (conseptual approach), pendekatan kasus (case approach), dan pendekatan perbandingan (comparative approach). Penelitian ini bersifat deskriptif analisis, deskriptif berarti usaha mengemukakan gejala-gejala secara lengkap di dalam aspek yang diselidiki agar jelas keadaan dan kondisinya. Menurut teori kepentingan (interest theory) pada benda asuransi melekat hak subjektif yang tidak berwujud. Kepentingan itu sifatnya absolut, artinya harus ada pada setiap objek asuransi dan mengikuti kemana saja benda asuransi itu berada. Kepentingan itu harus sudah ada pada benda asuransi pada saat asuransi diadakan atau setidak-tidaknya pada saat terjadi peristiwa yang menimbulkan kerugian (evenemen). Bagi tertanggung yang memiliki benda asuransi, kepentingannya melekat pada benda asuransinya. Pada konteks perjanjian asuransi, maka dalam mencapai kepentingan berdasar keadilan dan kemanfaatan tidak dapat hanya berdasar keuntungan penanggung, melainkan kemanfaatan berupa kesempatan bagi pihak yang seharusnya bisa jadi tertanggung demi kesetaraan.
\end{abstract}

Kata kunci: Asas Kepentingan, Karakteristik, Asuransi

\begin{abstract}
Object insurance is closely related to the theory of interest (interest theory) which is generally known in insurance law. The interest must already exist in the insurance object when the insurance is held or at least when the event that caused the loss (evenemen). Juridical problematic in this research is that there is no explanation related to the principle of interest in Law No. 14 of 2014 concerning Insurance (void norms), so there is no standardization of the principle of interests
\end{abstract}




\section{Zurnal Negara dan $\mathcal{X}$ eadilan \\ p-ISSN 2302-7010 e-ISSN 2721-9801}

and their characteristics. To find answers to problems in this study, the researcher will use certain legal theories as a basis for analyzing them. The theory includes; Legal Protection Theory, Legal Certainty Theory, Investment Theory, and Insurance Theory. The approach method used is normative juridical. This study uses 4 kinds of approaches, namely the statute approach, conceptual approach, case approach, and comparative approach. This research is a descriptive analysis, descriptive means an attempt to express the symptoms in full in the aspects being investigated to make it clear the conditions and conditions. According to the theory of interest (interest theory) on insurance objects inherent in intangible subjective rights. The importance is absolute, meaning that it must exist in every insurance object and follow it wherever the insurance object is located. The interest must already exist in the insurance object when the insurance is held or at least when the event that caused the loss (evenemen). For the insured who has insurance objects, their interests are inherent in the insurance object. In the context of insurance agreements, in achieving interests based on justice and benefits, it cannot only be based on the profits of the guarantor, but rather benefits in the form of opportunities for those who should be insured for equality.

Keywords: Principle of Interest, Characteristics, Insurance

\section{PENDAHULUAN}

Perasuransian di Indonesia berbanding lurus dengan pendapatan perkapita di Indonesia, maksudnya adalah semakin tinggi pendapatan dan harta yang dimiliki semakin besar risiko kehilangan yang dapat menimpanya, oleh karena itu semakin tinggi pendapatan, risiko kehilangan akan semakin besar maka dibutuhkan perlindungan dari ancaman risiko tersebut yakni melalui asuransi. Kemampuan ekonomi meningkat maka kemampuan masyarakat untuk membayar premi asuransi juga meningkat, bahkan sekarang banyak berkembang perusahaan asuransi di Indonesia. Sebagian masyarakat cenderung memisahkan sebagian penghasilannya untuk disimpan di Bank dari pada dipergunakan untuk asuransi. Kita harus mengakui, meskipun sudah banyak yang mengetahui tentang asuransi, namun masih banyak orang awam terhadap apa itu asuransi serta peraturan perundang-undangan tentang asuransi. Masyarakat masih sering merasakan bahwa asuransi tak melindungi aktivitasnya, bahkan cenderung merugikannya, meskipun kesan itu tidak semuanya benar. Dalam masyarakat modern seperti sekarang ini, perusahaan asuransi mempunyai peranan dan jangkauan yang luas, karena perusahaan asuransi mempunyai jangkauan uang menyangkut kepentingankepentingan ekonomi maupun kepentingan sosial. Di samping itu ia juga dapat menjangkau baik kepentingan individu, maupun kepentingan masyarakat luas, baik risiko individual maupun risiko kolektif. ${ }^{1}$

Salah satu lembaga keuangan non bank yang mempunyai peranan dalam pengerahan dana masyarakat untuk pembiayaan pembangunan adalah lembaga asuransi. Lembaga Asuransi sangat membantu dalam menanggung berbagai risiko yang dapat menimbulkan kerugian pada pelaksanaan pembangunan, kebutuhan akan hadirnya usaha perasuransian dirasakan juga oleh dunia usaha mengingat di satu pihak terdapat berbagai risiko yang secara sadar dan rasional dirasakan dapat

${ }^{1}$ Sri Redjeki Hartono, 1999, Hukum Asuransi dan Perusahaan Asuransi, Jakarta: Sinar Grafika, Hlm 5. 


\section{$\mathcal{H}$ urnal Negara dan Keadilan \\ p-ISSN 2302-7010 e-ISSN 2721-9801}

menganggu kesinambungan kegiatan usahanya. Perusahaan Asuransi sebagai perusahaan jasa, pada satu sisi menjual jasa kepada pelanggan, sedangkan pada sisi lain, perusahaan asuransi adalah sebagai investor dari tabungan masyarakat kepada investasi yang produktif. ${ }^{2}$ Secara tidak langsung asuransi atau lembaga asuransi adalah lembaga peralihan risiko. ${ }^{3}$ Setiap keputusan yang diambil manusia dalam menjalani kehidupannya selalu dipenuhi dengan risiko. Risiko adalah kemungkinan kerugian yang dialami, yang diakibatkan oleh bahaya yang mungkin terjadi, tetapi tidak diketahui lebih dahulu apakah akan terjadi dan kapan akan terjadi. Risiko dapat diartikan pula sebagai kerugian yang tidak pasti (uncertainty of financial loss) di dalamnya terdapat dua unsur yaitu: ketidakpastian dan kerugian. $^{4}$ Manfaat peralihan risiko inilah yang diperoleh konsumen (tertanggung). ${ }^{5}$

Dalam sudut pandang hukum, asuransi merupakan suatu perjanjian (perjanjian) pertanggungan risiko antara tertanggung dengan penanggung, penanggung berjanji akan membayar kerugian yang disebabkan risiko yang dipertanggungkan kepada tertanggung. ${ }^{6}$ Begitu beragam pengertian mengenai asuransi, yang pada pokoknya adalah menyangkut mengenai pengalihan dan atau manajemen risiko. Dalam hal ini Undang-Undang No. 40 Tahun 2014 tentang Perasuransian mendefinisikan asuransi adalah perjanjian antara dua pihak, yaitu perusahaan asuransi dan pemegang polis, yang menjadi dasar bagi penerimaan premi oleh perusahaan asuransi sebagai imbalan untuk:

a. memberikan pengantian kepada tertanggung atau pemegang polis karena kerugian, kerusakan, biaya yang timbul, kehilangan keuntungan, atau tanggung jawab hukum kepada pihak ketiga yang mungkin diderita tertanggung atau pemegang polis karena terjadinya suatu peristiwa yang tidak pasti, atau;

b. memberikan pembayaran yang didasarkan pada meninggalnya tertanggung atau pembayaran yang didasarkan pada hidupnya tertanggung dengan manfaat yang besarnya telah ditetapkan dan/atau didasarkan pada hasil pengelolaan dana. $^{7}$

Bahwa dilihat dari definisi asuransi tersebut di atas, maka dapat ditarik sebuah benang merah tentang adanya hubungan hukum yang berbentuk hubungan perjanjian antara pihak penanggung yang dalam hal ini adalah perusahaan asuransi dengan pihak tertanggung atau nasabah asuransi. Dengan adanya hubungan hukum dalam bentuk perjanjian tersebut maka harus ada kepentingan atas objek asuransi yang diasuransikan. Namun kepentingan tersebut maknanya tidak tercantum dalam Undang-Undang No. 40 Tahun 2014 tentang Perasuransian.

Dalam asuransi terdapat objek asuransi yang berupa kepentingan yang melekat pada benda, dan sejumlah uang yang disebut premi atau ganti kerugian. Melalui objek asuransi tersebut ada tujuan yang ingin dicapai oleh pihak-pihak. Penanggung bertujuan memperoleh pembayaran sejumlah premi sebagai imbalan

\footnotetext{
${ }^{2}$ Ibid., Hlm 8.

${ }^{3}$ Ibid., Hlm 50.

${ }^{4}$ Purwosutjipto, 2003, Pengertian Pokok Hukum Dagang Indonesia, Jakarta: Djambatan,

5 Abdulkadir Muhammad, 2006, Hukum Asuransi Indonesia, Bandung: Citra Aditya

${ }^{6} \mathrm{Ibid}, \mathrm{Hlm} 2$.

${ }^{7}$ Lihat UU No. 40 Tahun 2014 tentang Perasuransian.
} HIm 57. Bakti, Hlm 118. 


\section{Hurnal Negara dan $\mathcal{X}$ eadilan \\ p-ISSN 2302-7010 e-ISSN 2721-9801}

pengalihan risiko. Tertanggung bertujuan bebas dari risiko dan memperoleh penggantian jika timbul kerugian atas harta miliknya. Dalam perjanjian asuransi terkait pengalihan risiko dari tertanggung kepada penanggung diimbangi pembayaran premi oleh tertanggung yang seimbang denga beratnya risiko yang dialihkan meskipun dapat diperjanjikan kemungkinan prestasi itu tidak perlu seimbang. Dalam perjanjian untung-untungan (chance agreement) para pihak sengaja melakukan perbuatan untung-untungan yang tidak digantungkan pada prestasi yang seimbang, misalnya: perjudian dan pertaruhan.

Dalam perjanjian asuransi, unsur kepentingan merupakan syarat mutlak yang harus ada pada tertanggung. Apabila syarat ini tidak ada, maka ancamannya adalah asuransi itu batal (void). Dalam perjanjian untung-untungan, unsur kepentingan itu tidak ada. Dalam Pasal 250 KUHD ditentukan: "apabila seseorang mengadakan asuransi untuk diri sendiri atau untuk kepentingan pihak ketiga, pada saat diadakan asuransi itu tertanggung atau pihak ketiga yang bersangkutan tidak mempunyai kepentingan atas benda asuransi, maka penanggung tidak berkewajiban mengganti kerugian”. Dengan demikian jelaslah bahwa kepentingan tertanggung dalam perjanjian asuransi merupakan syarat mutlak, jika kepentingan itu tidak ada, maka mengakibatkan asuransi itu batal.

Objek tertentu dalam perjanjian asuransi adalah objek yang diasuransikan dapat berupa harta kekayaan dan kepentingan yang melekat pada harta kekayaan, dapat pula berupa jiwa atau raga manusia. Objek tertentu berupa harta kekayaan dan kepentingan yang melekat pada harta kekayaan terdapat pada perjanjian asuransi kerugian. Objek tertentu berupa jiwa atau raga manusia terdapat perjanjian asuransi jiwa. Pengertian objek tertentu adalah bahwa identitas objek asuransi tersebut harus jelas dan pasti. Apabila berupa harta kekayaan, harta kekayaan apa, berapa jumlah dan ukurannya, di mana letaknya, apa mereknya, buatan mana, berapa nilainya dan sebagainya. Apabila berupa jiwa atau raga, atas nama siapa, berapa umurnya, apa hubungan keluarganya, di mana alamatnya, dan sebagainya. Karena yang mengasuransikan objek itu adaah tertanggung, maka dia harus mempunyai hubungan langsung atau tidak langsung dengan objek asuransi itu. Dikatakan ada hubungan langsung apabila tertanggung memiliki sendiri harta kekayaan, jiwa atau raga yang menjadi objek asuransi. Dikatakan ada hubungan tidak langsung apabila tertanggung hanya mempunyai kepentingan atas objek asuransi. Tertanggung harus dapat membuktikan bahwa dia adalah benar sebagai pemilik atau mempunyai kepentingan atas objek asuransi. Apabila tertanggung tidak dapat membuktikannya, maka akan timbul anggapan bahwa tertanggung tidak mempunyai kepentingan apa-apa, hal mana mengakibatkan asuransi batal (null and void). Undang-undang tidak akan membenarkan, tidak akan mengakui orang yang mengadakan asuransi, tetapi tidak mempunyai kepentingan (interest). Walaupun orang yang mengadakan asuransi itu tidak mempunyai hubungan langsung dengan objek asuransi, dia harus menyebutkan untuk kepentingan siapa asuransi itu diadakan. Jika tidak demikian, maka asuransi itu dianggap tidak ada. Menurut ketentuan Pasal 599 KUHD, dianggap tidak mempunyai kepentingan adalah orang yang mengasuransikan benda yang oleh undang-undang dialarang diperdagangkan dan kapal yang mengangkut barang yang dilarang tersebut. Apabila diasuransikan juga, maka asuransi tersebut batal.

Benda asuransi adalah benda yang menjadi objek perjanjian asuransi (object

of insurance). Benda asuransi adalah harta kekayaan yang mempunyai nilai 


\section{$\mathcal{H}$ urnal Negara dan Keadilan \\ p-ISSN 2302-7010 e-ISSN 2721-9801}

ekonomi, yang dapat dihargai dengan sejumlah uang. Benda asuransi selalu berwujud misalnya gedung pertokoan, rumah, kapal. Benda asuransi selalu diancam oleh bahaya atau peristiwa yang terjadi yang mengakibatkan benda asuransi dapat rusak, hilang, musnah, atau berkurang nilainya.

Benda asuransi erat hubungannya dengan teori kepentingan (interest theory) yang secara umum dikenal dalam hukum asuransi. Menurut teori kepentingan, pada benda asuransi melekat hak subjektif yang tidak berwujud, karena benda asuransi dapat rusak, hilang, musnah, atau berkurang nilainya. Dalam literatur hukum asuransi, hak subjektif ini disebut kepentingan (interest). Kepentingan itu sifatnya absolut, artinya harus ada pada setiap objek asuransi dan mengikuti ke mana saja benda asuransi itu berada. Kepentingan itu harus sudah ada pada benda asuransi pada saat asuransi diadakan atau setidak-tidaknya pada saat terjadi peristiwa yang menimbulkan kerugian (evenemen). Dengan demikian, jika asas kepentingan ini tidak terdapat standarisasi dan karakteristik tentang makna, maka hal inilah yang menjadi problematika teoritis dalam penelitian tesis ini.

Problematika yuridis dalam penelitian ini adalah belum adanya penjelasan terkait asas kepentingan dalam Undang-Undang No. 14 Tahun 2014 tentang Perasuransian (kekosongan norma), sehingga tidak terdapat standarisasi tentang asas kepentingan beserta karakteristiknya. Di negara-negara maju asuransi mendapat tempat utama bahkan kemajuan negara itu didorong dan seiring dengan kemajuan asuransinya. Asuransi merupakan jaminan, payung kemajuan dan kehidupan.

Problematika filsafati dalam penelitian ini yakni keberadaan asuransi akan menciptakan pertumbuhan ekonomi. Dengan tidak diberikan tentang penjelasan asas kepentingan dalam undang-undang asuransi, maka berimplikasi terhadap tidak adanya kepastian hukum dalam perjanjian asuransi.

\section{METODE PENELITIAN}

Metode pendekatan yang digunakan dalam penelitian adalah bersifat yuridis normatif. Penelitian hukum normatif dilakukan mengutamakan cara meneliti bahan pustaka atau data normatif dilakukan mengutamakan cara meneliti bahan pustaka atau data sekunder yang meliputi bahan hukum primer dan bahan hukum sekunder.

Penelitian hukum normatif ini dilakukan dengan mengkaji atau melakukan inventarisasi hukum, menemukan asas-asas hukum, menemukan in concreto sejarah hukum, serta pendekatan perundang-undangan khususnya ketentuan perundang-undangan yang berkaitan dengan asuransi. Pendekatan yuridis normatif mengkaji, menguji dan menerapkan asas-asas hukum serta prinsipprinsip umum hukum asuransi.

Penelitian tesis ini menggunakan 4 macam pendekatan, yakni pendekatan perundang-undangan (statute approach), pendekatan konseptual (conseptual approach), pendekatan kasus (case approach), dan pendekatan perbandingan (comparative approach).

Penelitian hukum normatif tidak mengenal adanya data-data. Guna memecahkan isu hukum sekaligus memberikan penjelasan mengenai apa yang seharusnya diperlukan sumber-sumber penelitian. Sumber bahan hukum dalam disertasi ini menggunakan sumber bahan hukum primer dan sekunder. 


\section{Hurnal Negara dan $\mathcal{X}$ eadilan \\ p-ISSN 2302-7010 e-ISSN 2721-9801}

Penelitian ini adalah penelitian kepustakaan. Bahan hukum yang dihimpun dalam penelitian ini dihasilkan dari studi kepustakaan. Oleh karena itu teknik pengumpulan bahan hukum yang digunakan dalam penelitian ini adalah telaah pustaka dan dokumenter. Pengumpulan bahan hukum dilakukan dengan cara penelusuran yaitu (1) menelusuri norma-norma yang mengatur tentang asuransi, dan (2) menganalisis secara mendalam sehingga dapat menjawab rumusan masalah.

Penelitian ini bersifat deskriptif analisis, deskriptif berarti usaha mengemukakan gejala-gejala secara lengkap di dalam aspek yang diselidiki agar jelas keadaan dan kondisinya. Sedangkan analisis merupakan usaha memecahkan masalah dengan persamaan dan perbedaan gejala yang ditemukan, mengukur dimensi suatu gejala, menetapkan standar, menetapkan hubungan antar gejalagejala yang ditemukan dan sebagainya.

\section{PEMBAHASAN}

Benda asuransi adalah benda yang menjadi objek perjanjian asuransi (object of insurance). Benda asuransi adalah harta kekayaan yang mempunyai nilai ekonomi, yang dapat dihargai dengan sejumlah uang. Benda asuransi selalu berwujud, mislanya gedung pertokoan, rumah, kapal. Benda asuransi erat hubungannya dengan teori kepentingan (interest theory) yang secara umum dikenal dalam hukum asuransi. Menurut teori kepentingan, pada benda asuransi melekat hak subjektif yang tidak berwujud. Karena benda asuransi dapat rusak, hilang, musnah, atau berkurang nilainya, maka hak subjektif juga dapat rusak, hilang, musnah, atau berkurang nilainya. Dalam literatur hukum asuransi, hak subjektif ini disebut kepentingan (interest). Kepentingan itu sifatnya absolut, artinya harus ada pada setiap objek asuransi dan mengikuti kemana saja benda asuransi itu berada. Kepentingan itu harus sudah ada pada benda asuransi pada saat asuransi diadakan atau setidak-tidaknya pada saat terjadi peristiwa yang menimbulkan kerugian (evenemen).

Keunggulan teori kepentingan (interest theory) adalah sebagai upaya pencegahan terjadinya perbuatan memperkaya diri tanpa hak dengan mengharapkan memperoleh ganti kerugian dari penanggung dalam hal terjadi evenemen melalui asuransi tanpa kepentingan. Dalam hal ini penanggung dilindungi dari perbuatan spkeulatif pihak yang tidak jujur. Akan tetapi, kelemahannya adalah tertanggung yang beritikad baik dirugikan oleh kebatalan asuransi akibat terlambatnya kuasa tertulis dari pemilik barang, sedangkan evenemen terjadi mendahului kuasa tertulis tersebut.

Tidak adanya kepentingan tertanggung pada benda asuransi dapat menimbulkan akibat hukum bahwa tertanggung tidak berhak menuntut ganti kerugian dalam hal terjadi evenemen walaupun tertanggung telah membayar premi kepada penanggung. Tertanggung yang tidak berkepentingan yang menerima pembayaran ganti kerugian akibat evenemen sama saja dengan memperkaya diri tanpa hak yang bertentangan dengan asas hukum yang sangat dijunjung tinggi dalam kehidupan bermasyarakat. Dengan kata lain, setiap asuransi yang diadakan oleh tertanggung yang tidak berkepentingan dianggap tidak pernah ada (no interest no insurance). Bagaimana halnya dengan premi yang sudah dibayar kepada penanggung, apakah dapat dituntut pengembaliannya, premi 


\section{$\mathcal{H}$ urnal Negara dan Keadilan \\ p-ISSN 2302-7010 e-ISSN 2721-9801}

yang sudah dibayar dianggap sebagai kerugian bagi tertanggung yang tidak jujur, sehingga tidak dapat dituntut pengembaliannya.

Benda asuransi adalah harta kekayaan., karena kepentingan itu melekat pada benda asuransi, maka kepentingan juga adalah harta kekayaan. Sebagai harta kekayaan, kepentingan memiliki unsur-unsur bersifat ekonomi. Menurut ketentuan Pasal $268 \mathrm{KUHD},{ }^{8}$ asuransi dapat mengenai segala macam kepentingan yang dapat dinilai dengan uang., diancam oleh bahaya, dan tidak dikecualikan oleh undang-undang. Berdasarkan ketentuan pasal ini dapat ditentukan kriteria kepentingan yaitu:

a. harus ada pada setiap asuransi (Pasal 250 KUHD);

b. harus dapat dinilai dengan uang;

c. harus diancam oleh bahaya;

d. harus tidak dikecualikan oleh undang-undang.

Tidak dikecualikan oleh undang-undang artinya tidak dilarang undangundang, tidak bertentangan dengan ketertiban umum/kesusilaan. Bagi tertanggung yang memiliki benda asuransi, kepentingannya melekat pada benda asuransinya. Dalam hal ini benda asuransi dan kepentingan berada dalam 1 (satu) tangan. Akan tetapi, mungkin juga terjadi bahwa benda asuransi dan kepentingan itu tidak berada dalam 1 (satu) tangan, tetapi terpisah. Benda asuransi dalam tangan pemiliknya, sedangkan kepentingan berada dalam tangan orang lain, misalnya pemegang jaminan, penyewa kapal, ataupun pemakai rumah.

Pemegang jaminan mengasuransikan gedung pertokoan yang menjadi jaminan kredit terhadap bahaya kebakaran, agar kepentingannya atas gedung pertokoan itu tidak musnah atau berkurang nilainya karena kebakaran. Di sini benda asuransi adalah gedung pertokoan berada di tangan pemilik gedung, sedangkan kepentingan adalah hak jaminan atas gedung berada di tangan pemegang jaminan, yaitu pemberi kredit. Jika gedung pertokoan itu terbakar kepentingan tertanggung selaku pemegang jaminan dapat musnah atau berkurang nilainya.

Penyewa kapal mengasuransikan kapal yang disewanya terhadap bahaya laut agar kepentingannya yang melekat pada kapal itu tidak lenyap atau hilang karena karam atau disita oleh penguasa negara lain. Di sini benda asuransi adalah kapal berada di tangan pemilik kapal. Jika kapal itu lenyap karena karam atau hilang karena disita oleh penguasa negara lain, kepentingan tertanggung selaku penyewa kapal dapat lenyap atau hilang.

Objek asuransi yang telah diuraikan ini baru meliputi objek asuransi kerugian. Setelah itu, ada juga objek asuransi jumlah, misalnya pada asuransi jiwa dan asuransi kecelakaan. Objek asuransi jumlah bukan benda, melainkan jiwa atau raga manusia yang terancam peristiwa yang menjadi sebab kematian atau kecelakaan. Objek asuransi jumlah tidak dapat dinilai dengan uang, tetapi sejumlah uang dapat dijadikan ukuran pembayaran santunan jika terjadi peristiwa yang menjadi sebab kematian atau kecelakaan. Penetapan sejumlah uang sebagai santunan hanya untuk tujuan praktis, yaitu memudahkan perhitungan pembayaran santunan yang jumlahnya sudah ditetapkan dalam perjanjian atau undang-undang.

Dalam setiap asuransi, kepentingan itu harus ada. Jika tidak ada kepentingan atas benda yang diasuransikan, penanggung tidak diwajibkan

${ }^{8}$ Lihat Pasal 268 KUHD 


\section{Hurnal Negara dan $\mathcal{X}$ eadilan \\ p-ISSN 2302-7010 e-ISSN 2721-9801}

membayar klaim ganti kerugian (Pasal 250 KUHD). ${ }^{9}$ Ini berarti jika tidak ada kepentingan, tidak ada pula asuransi. Jika terjadi peristiwa yang menimbulkan kerugian, tidak ada klaim ganti kerugian bagi tertanggung yang tidak berkepentingan. Jadi, kepentingan itu merupakan syarat mutlak dalam setiap asuransi.

Dalam setiap asuransi, jika benda yang diasuransikan lenyap atau rusak, tertanggung yang berkepentingan akan mendapat ganti kerugian dari penanggung. Akan tetapi, haknya itu hanya sampai pada jumlah nilai kepentingannya. Bagi pemegang jaminan hanya berhak sampai pada jumlah nilai piutangnya. Jumlah selebihnya yang masih ada tetap menjadi hak pemilik benda asuransi. Dalam asuransi kerugian, kepentingan harus dapat dinilai dengan uang (Pasal 268 KUHD). Jadi dapat ditentukan berapa besarnya jumlah yang diasuransikan. Hal ini penting untuk menentukan berapa jumlah premi yang harus dibayar oleh tertanggung, berapa ganti kerugian yang harus dibayar oleh penanggung jika terjadi peristiwa yang menimbulkan kerugian.

Bagaimana dengan asuransi jumlah yang objek asuransinya tidak dapat dinilai dengan uang? apa yang dijadikan ukuran untuk menentukan jumlah asuransi, jumlah premi yang dibayar oleh tertanggung dan jumlah santunan yang wajib dibayar oleh penanggung jika terjadi peristiwa penyebab kematian atau kecelakaan? sejumlah uang selalu dijadikan ukuran yang dianggap pantas/layak/patut menurut berat ringannya akibat yang ditimbulkan oleh peristiwa, misalnya kematian lebih berat dari pada kecelakaan biasa. Cacat seumur hidup lebih berat dari pada cacat yang dapat disembuhkan. Penentuan ukuran sejumlah uang yang diperjanjikan antara tertanggung dengan penanggung dan menurut ketentuan yang ditetapkan oleh undang-undang.

Apabila benda asuransi berpindah kepada pihak lain, misalnya karena dijual, maka asuransi mengikuti kepentingan yang melekat pada benda asuransi itu. Segala hak dan kewajiban tertanggung lama berpindah kepada tertanggung baru, kecuali jika diperjanjikan sebaliknya antara tertanggung lama dan penanggung (Pasal 263 ayat (1) KUHD). Akan tetapi, jika pembeli atau pemilik baru benda asuransi itu menolak untuk mengoper asuransinya, sedangkan tertanggung lama masih mempunyai kepentingan terhadap benda yang diasuransikan, maka asuransi itu tetap berjalan untuk kepentingan tertanggung lama (Pasal 263 ayat (2) KUHD). Jika tertanggung lama sudah tidak berkepentingan lagi, maka pemilik baru harus memberitahukan kepada penanggung untuk menghentikan asuransi itu.

Misalnya, Amat pemilik restoran mengasuransikan perlengkapan restorannya terhadap bahaya kebakaran pada perusahaan asuransi PK. Kemudian, Amat menjual alat perlengkapan tersebut kepada Bidin dengan perjanjian pinjam pakai. Hak milik telah diserahkan kepada Bidin, tetapi Bidin belum membayar harganya. Sebagai jaminan hutangnya itu Bidin menjanjikan kepada Amat boleh menguasai alat perlengkapan tersebut. Berdasarkan perjanjian pinjam pakai, Amat masih memerlukan alat perlengkapan itu untuk menjalankan usahanya. Di samping itu, Amat masih berkepentingan karena dia sebagai pemegang gadai.

Dengan penjualan alat perlengkapan tersebut kepada Bidin, asuransi mengikuti benda asuransi (kepentingan), sehingga asuransi berpindah juga kepada

${ }^{9}$ Lihat Pasal 250 KUHD 


\section{Jurnal Negara dan Zeadilan \\ p-ISSN 2302-7010 e-ISSN 2721-9801}

Bidin. Sebagai pemilik baru, Bidin mempunyai hak dan kewajiban selaku tertanggung dalam asuransi itu. Jika Bidin menolak pengalihan asuransi itu, Amat masih mempunyai kepentingan atas benda asuransi. Oleh karena itu asuransi diteruskan berlakunya untk kepentingan Amat sebagai pemegang gadai, Amat mempunyai hak dan kewajiban dalam asuransi itu. Apabila Amat sudah tidak berkepentingan lagi, maka dia harus memberitahukan hal itu kepada penanggung perusahaan asuransi PK guna menghentikan asuransi itu. ${ }^{10}$

Seperti telah diuraikan sebelumnya, dapat setiap asuransi harus ada kepentingan atas benda yang diasuransikan. Persoalannya adalah bilamana kepentingan itu harus ada? Menurut ketentuan Pasal 250 KUHD, kepentingan harus sudah ada pada saat diadakan asuransi. Hal ini berarti apabila pada saat membuat perjanjian asuransi tertanggung tidak mempunyai kepentingan, kemudian terjadi peristiwa yang menimbulkan kerugian, penanggung tidak berkewajiban membayar klaim ganti kerugian.

Ketentuan Pasal 250 KUHD selayaknya ditunjukkan kepada tertanggung sebagai suatu isyarat bahwa pada waktu mengadakan asuransi, tertanggung perlu menyatakan dengan tegas dan jelas apa kepentingannya mengadakan asuransi itu. Dengan adanya kepentingan, sejumlah premi dapat dibayar, sehingga asuransi berjalan. Jika terjadi peristiwa yang menimbulkan kerugian, tertanggung yang berkepentingan berhak mengklaim pembayaran ganti kerugian dari penanggung. Adalah logis bahwa setiap orang yang mengadakan asuransi itu ada kepentingan, baik bagi dirinya sendiri ataupun bagi pihak ketiga. Jika tidak mempunyai kepentingan, buat apa mengadakan perjanjian asuransi dan mengeluarkan uang untuk membayar premi. Bagi mereka yang beritikad buruk mengadakan asuransi seolah-olah berkepentingan, sudah selayaknya tidak dilindungi oleh undangundang. Artinya, penanggung tidak berkewajiban membayar ganti kerugian jika terjadi peristiwa terhadap benda yang diasuransikan, walaupun tertanggung yang tidak jujur itu telah membayar premi, asuransi bukanlah untung-untungan. Misalnya, tertanggung mengasuransikan sebuah mobil terhadap bahaya tabrakan dengan harapan jika terjadi tabrakan dia akan mendapat ganti rugi. Mobil tersebut milik otang lain yang dipinjam oleh tertanggung. Akan tetapi, dia mengasuransikan mobil tersebut seolah-olah miliknya sendiri, padahal dia tidak berkepentingan sama sekali. Kemudian, terjadi tabrakan yang menimbulkan kerugian. Pihak yang menderita kerugian adalah pemilik mobil, bukan tertanggung yang meminjam mobil itu. Dalam hal ini penanggung tidak berkewajiban membayar klaim ganti kerugian menurut Pasal 250 KUHD. Peminjam mobil itu harus bertanggung jawab atas kerugian yang diderita oleh pemilik mobil. Lain halnya jika pemegang mobil itu adalah orang yang berpiutang dan mobil itu sebagai jaminannya. Pada mobil itu melekat kepentingannya. Jika mobil bertabrakan, maka kepentingannya akan berkurang atau lenyap. Jadi, jika dia mengasuransikan mobil tersebut, dia dapat mengklaim ganti rugi kepada penanggungnya karena dia mempunyai kepentingan.

Menurut Dorhout Mees, kepentingan itu harus sudah ada pada saat terjadi kerugian. Vollmar juga mengatakan bahwa kepentingan itu harus sudah ada pada saat terjadi peristiwa, sehingga tertanggung berhak mengklaim ganti kerugian. Jadi, menurut kedua peneliti hukum tersebut, kepentingan tidak perlu harus ada

${ }^{10}$ Abdulkadir Muhammad, Op. Cit., Hlm 90-91. 


\section{Hurnal Negara dan $\mathcal{X}$ eadilan \\ p-ISSN 2302-7010 e-ISSN 2721-9801}

pada saat perjanjian asuransi dibuat, tetapi pada saat terjadi peristiwa yang menimbulkan kerugian. Pada saat itulah muncul kepentingan guna menentukan ada atau tidaknya ganti kerugian. Hal ini dapat dimaklumi karena pada hakikatnya asuransi itu baru mempunyai arti bagi tertanggung justru pada saat terjadi peristiwa. ${ }^{11}$

Konkretnya adalah sebagai berikut, Amat pemilik rumah mengasuransikan rumahnya terhadap bahaya kebakaran. Kemudian, rumah tersebut dijual kepada Bidin. Pada saat terjadi perjanjian jual beli, rumah tadi terbakar habis. Walaupun telah terjadi jual beli, kepentingan masih ada pada Amat karena rumah belum diserahkan menurut hukum. Pihak yang berhak mengklaim ganti kerugian kepada penanggung adalah Amat. Jika rumah telah diserahkan kepada Bidin, barulah hak milik beralih, sehingga kepentingan juga beralih. Dengan demikian, Bidin berhak mengkalim ganti kerugian kepada penanggung. Apabila harga rumah belum dibayar oleh Bidin kepada Amat, maka Bidin harus membayar kepada Amat apa yang menjadi haknya dari hasil klaim ganti kerugian itu setelah dikurangi biayabiaya sekedar itu telah dibayar oleh Bidin. Inilah yang dimaksud oleh peneliti hukum bahwa kepentingan harus sudah ada pada saat terjadi peristiwa yang menimbulkan kerugian. Sehubungan dengan contoh tadi, perhatikan juga ketentuan Pasal 263 KUHD (asuransi mengikuti kepentingan). ${ }^{12}$

Dalam praktiknya tidak akan menimbulkan kesulitan dalam soal penentuan kapan adanya kepentingan karena segala sesuatunya sudah diatur oleh penanggung dan sudah ditentukan dalam polis. Oleh karena itu, bergantung pada tertanggung mau atau tidak mengadakan asuransi dengan syarat-syarat yang telah ditentukan oleh penanggung. Saat adanya kepentingan seperti ditentukan dalam Pasal 250 KUHD, mempunyai fungsi yang jelas dalam hal kepentingan itu. Akan tetapi, jika tertanggungnya berganti, kepentingan beralih kepada tertanggung baru, kecuali jika diperjanjikan sebaliknya oleh tertanggung lama dan penanggung (Padal 263 KUHD). ${ }^{13}$

Jumlah yang diasuransikan (the sum insured) adalah jumlah yang dipakai sebagai ukuran untuk menentukan jumlah maksimum ganti kerugian yang wajib dibayar oleh penanggung dalam suatu asuransi kerugian. Jumlah yang diasuransikan erat sekali hubungannya dengan nilai benda asuransi. Dengan ditentukan junlah yang diasuransikan, dapat diketahui apakah asuransi itu di bawah nilai benda asuransi (under insurance), atau sama dengan nilai benda asuransi (full insurance), atau melebihi nilai benda asuransi (over insurance). Dengan demikian, dapat ditentukan jumlah maksimum ganti kerugian yang dapat dibayar jika timbul kerugian akibat peristiwa yang menjadi beban penanggung.

Menurut ketentuan Pasal 253 ayat (1) KUHD, asuransi yang melebihi jumlah nilai benda atau kepentingan yang sesungguhnya hanya sah sampai jumlah nilai benda tersebut. Apabila jumlah yang diasuransikan lebih besar dari pada nilai benda sesungguhnya, penanggung hanya bertanggung jawab membayar klaim ganti rugi sampai jumlah nilainya, sebuah rumah diasuransikan terhadap bahaya kebakaran dengan jumlah asuransi Rp 150.000.000 (seratus lima puluh juta rupiah). Nilai rumah sesungguhnya Rp 100.000.000 (seratus juta rupiah). Jika

11 Davidson, Daniel, et al, 1997, Comprehensive Business Law, Principles and Cases,Kent Publishing Company, Boston, Massachusetts, HIm 3.

${ }^{12}$ Lihat Pasal 263 KUHD

${ }^{13}$ Abdulkadir Muhammad, Op. Cit., Hlm 93-94. 


\section{$\mathcal{H}$ urnal Negara dan Keadilan \\ p-ISSN 2302-7010 e-ISSN 2721-9801}

rumah tersebut terbakar habis, penanggung berkewajiban memenuhi klaim ganti kerugian hanya sampai jumlah Rp 100.000.000 (seratus juta rupiah).

Menurut ketentuan Pasal 253 ayat (2) KUHD, apabila suatu benda tidak diasuransikan dengan nilai penuh, maka jika timbul kerugian, penanggung hanya diwajibkan memenuhi klaim ganti kerugian menurut perbandingan antara bagian yang diasuransikan dan bagian yang tidak diausransikan. Misalnya, sebuah rumah diausransikan terhadap bahaya kebakaran sejumlah Rp 80.000.000 (delapan puluh juta rupiah). Nilai rumah sesungguhnya Rp 100.000.000 (seratus juta rupiah). Kemudian, terjadi kebakaran yang menimbulkan kerugian Rp 60.000 .000 (enam puluh juta rupiah). Perbandingan antara jumlah yang diasuransikan dan jumlah yang tidak diasuransikan adalah 8:2, jumlah perbandingan adalah 10. Jumlah klaim ganti kerugian yang dipenuhi oleh penanggung adalah 8/10x Rp 60.000.000 (enam puluh juta rupiah) $=\operatorname{Rp} 48.000 .000$ (empat puluh delapan juta rupiah). Akan tetapi, jika rumah itu terbakar habis, maka klaim ganti kerugian maksimum yang dapat dipenuhi oleh penanggung hanya Rp 80.000.000 (delapan puluh juta rupiah) sebab jumlah yang diasuransikan itu adalah jumlah maksimum ganti kerugian yang dapat dibayar oleh penanggung.

Ketentuan Pasal 253 ayat (2) KUHD masih dapat disimpangi oleh pihakpihak, asalkan diperjanjikan dengan tegas dalam polis tanpa memperhatikan asas keseimbangan, kerugian yang menimpa benda asuransi itu akan diganti sepenuhnya sampai jumlah yang diasuransikan (Pasal 253 ayat (3) KUHD). Ini berarti jika dalam contoh di atas kerugian yang timbul berjumlah Rp 60.000.000 (enam puluh juta rupiah), penanggung akan membayar Rp 60.000.000 (enam puluh juta rupiah) itu. Apabila kerugian yang timbul berjumlah Rp 80.000.000 (delapan puluh juta rupiah), penanggung akan membayar jumlah Rp 80.000.000 (delapan puluh juta rupiah). Klausula yang demikian ini disebut premier risque dan harus dinyatakan dengan tegas dalam polis.

Klausula premier risque ini dimungkinkan karena sulit menentukan batasbatas nilai penuh kepentingan dalam jenis asuransi itu. Dengan demikian, sulit pula menentukan batas-batas risiko seluruhnya. Klausula ini biasa diadakan dalam asuransi terhadap bahaya yang jarang menimbulkan kerugian total benda asuransi, melainkan hanya sebagian saja.

Asuransi yang terjadi adalah yang tidak dalam jumlah penuh, artinya jumlah yang diasuransikan selalu di bawah nilai benda asuransi sesungguhnya. ${ }^{14}$ Hal ini ada keuntungannya bagi penanggung, yaitu tertanggung masih diharapkan mempunyai sikap berhati-hati menjaga keselamatan benda yang diasuransikan itu karena sebagian dari benda asuransi masih menjadi tanggungannya sendiri. Akan tetapi, jika diasuransikan dalam jumlah penuh, artinya jumlah yang diasuransikan itu meliputi seluruh nilai benda sesungguhnya (full insurance), ada kecenderungan bahwa tertanggung kurang berhati-hati menjaga keselamatan benda asuransi dari ancaman bahaya. Alasan yang dikemukakan oleh Prof. Emmy Simanjuntak adalah tertanggung beranggapan bahwa jika terjadi peristiwa yang menimbulkan kerugian, ada yang akan membayar ganti kerugian kepadanya. ${ }^{15}$ Namun, menurut

${ }^{14}$ Djoko Prakoso, I Ketut Murtika, 1989, Hukum Asuransi Indonesia, Ctk. Kedua, PT. Bina Aksara, Jakarta, Hlm 13.

${ }^{15}$ Emmy Pangaribuan Simanjuntak, 1997, Beberapa Aspek Hukum Dagang di Indonesia, Jakarta: Bina Cipta, Hlm 51. 


\section{Hurnal Negara dan $\mathcal{X}$ eadilan \\ p-ISSN 2302-7010 e-ISSN 2721-9801}

hemat peneliti, perusahaan asuransi kerugian dapat mempertimbangkan benda apa yang disetujui untuk diadakan asuransi dengan nilai penuh dan yang tidak dengan nilai penuh. Sekiranya suatu benda diasuransikan dengan nilai penuh, perusahaan asuransi kerugian mengukur kemampuannya dan untuk mengatasi ketidakmampuannya itu, dia dapat pula berhubungan dengan perusahaan reasuransi.

Di Indonesia, pada asuransi yang diadakan untuk suatu jangka waktu tertentu atau menurut perjalanan, jumlah yang diausransikan itu adalah jumlah maksimum ganti kerugian yang dapat dibayar oleh penanggung untuk seluruh jangka waktu asuransi atau untuk 1 (satu) perjalanan. Akan tetapi, di Inggris lain lagi, jumlah yang diausransikan itu bukan sebagai jumlah maksimum ganti kerugian. Apabila dalam jangka waktu yang ditentukan itu ada beberapa kali terjadi peristiwa yang menimbulkan kerugian, semua kerugian itu diganti oleh penanggung meksipun jumlahnya mungkin melebihi jumlah yang diausransikan. Hal ini ditentukan dalam Pasal 777 ayat (1) The Marine Insurance Act 1906 sebagai berikut: " Unless the policy otherwise provides and subject to provisions of this act, the insurer is liable for successive losses even thoguh teh total amount of such losses may exceed the sum insured". ${ }^{16}$

Apabila tertanggung dan penanggung memperjanjikan lain dan hal itu harus dinyatakan dalam polis, maka jumlah ganti kerugian itu dapat dibatasi sampai dengan jumlah yang dipertanggungkan. Inilah yang dimaksud dengan kalimat unless the policy otherwise provides dalam ketentuan tersebut tadi.

Dalam Pasal 256 KUHD yang mengatur tentang isi polis tidak terdapat butir ketentuan mengenai nilai benda asuransi, yang dicantumkan adalah butir mengenai benda yang diasuransikan. Mungkin dalam butir tersebut tercakup juga penialian benda yang diasuransikan. Pasal 273 KUHD mengatur tentang nilai benda asuransi yang tidak dinyatakan dalam polis. Pasal 274 KUHD mengatur tentang nilai benda asuransi yang dinyatakan dalam polis. Berdasarkan ketentuan kedua pasal tersebut dapat disimpulkan bahwa tidak ada keharusan pencantuman nilai benda asuransi pada waktu mengadakan asuransi. Nilai benda asuransi dinyatakan atau tidak dalam polis tidak menjadi persoalan. Tidak ada keharusan pencantuman nilai benda asuransi dalam polis diperkuat oleh alasan dicantumkan dalam polis penanggung dapat mengajukan alasan untuk tidak menyetujui nilai benda asuransi apabila menurut dugaannya nilai tersebut terlalu tinggi. Di samping itu, mungkin juga terjadi bahwa nilai benda asuransi pada saat diadakan asuransi tidak sama atau menjadi berubah pada saat terjadi peristiwa yang menimbulkan kerugian itu. Apabila pada waktu mengadakan asuransi, nilai benda asuransi belum dinyatakan dalam polis, maka jika terjadi peristiwa yang menimbulkan kerugian, tertanggung memberitahukan kepada penanggungnya besar nilai benda asuransi itu dengan menggunakan segala macam alat bukti (Pasal 273 KUHD). Alat-alat bukti tersebut digunakan untuk meyakinkan penanggung bahwa nilai benda asuransi itu benar dan layak. Polis yang tidak mencantumkan nilai benda asuransi disebut polis terbuka (open policy). ${ }^{17}$

Pada waktu mengadakan asuransi, tertanggung dan penanggung mengadakan kesepakatan tentang nilai benda asuransi dengan memperhatikan

${ }^{16}$ Lihat Pasal 777 ayat (1) The Marine Insurance Act 1906

${ }^{17}$ Junaedy Ganie, 2013, Hukum Asuransi Indonesia, Ctk. Jakarta: Kedua, Sinar Grafika, Hlm 32. 


\section{$\mathcal{H}$ urnal Negara dan Keadilan \\ p-ISSN 2302-7010 e-ISSN 2721-9801}

keadaan, sifat, dan tujuan benda itu. Apabila sudah ada kesepakatan, maka nilai benda asuransi dicantumkan dalam polis, sehingga terdapat nilai benda yang tetap. Jika terjadi peristiwa yang menimbulkan kerugian, nilai benda yang dicantumkan itulah dijadikan dasar perhitungan ganti kerugian. Polis yang memuat nilai benda asuransi disebut polis bernilai (valued policy).

Persoalan penting adalah pengertian nilai benda asuransi karena nilai itu dapat berubah-ubah dari waktu ke waktu bergantung pada sifat dan keadaan benda tersebut. Benda tetap seperti rumah dan tanah, nilainya tidak akan banyak mengalami perubahan, bahkan mungkin tetap atau meningkat. Benda yang mudah susut, rusak, atau busuk seperti gas, hasil pertanian, dan buah-buahan yang sudah masak akan mengalami perubahan nilai atau penyusutan, sehingga nilai pada waktu diasuransikan akan menjadi berbeda dengan nilai pada waktu terjadi peristiwa yang menimbulkan kerugian. Demikian juga apabila nilai benda tersebut dihubungkan dengan tujuan penggunaannya, misalnya benda itu diperdagangkan atau untuk dipakai sendiri, seperti mobil, perlengkapan, rumah tangga, atau semen untuk bangunan. Nilai benda tersebut dapat berubah dan berbeda antara nilai benda pada waktu dibeli dan pada waktu dijual lagi. Dengan kata lain, nilai benda pada waktu diadakan asuransi berbeda dengan nilai benda pada waktu diadakan asuransi berbeda dengan nilai benda pada waktu terjadi peristiwa yang menimbulkan kerugian itu. Benda yang tidak diperdagangkan, misalnya benda sejarah atau benda pusaka, mungkin tidak mengalami perubahan nilai, baik pada waktu diadakan asuransi maupun pada waktu terjadi peristiwa yang merugikan itu. Apabila benda asuransi itu mengalami kerusakan ataupun kehancuran akibat peristiwa terhadap mana benda itu diasuransikan, nilai yang manakah yang dijadikan dasar perhitungan ganti kerugian, apakah nilai benda pada waktu diadakan asuransi atau nilai benda pada waktu terjadi peristiwa yang merugikan itu? Jika berpedoman pada tujuan asuransi, yaitu untuk memberikan ganti kerugian yang sungguh-sungguh dialami oleh tertanggung, maka wajarlah apabila nilai benda pada waktu terjadi peristiwa yang menimbulkan kerugian itu. Karena yang dijadikan dasar perhitungan adalah nilai pada waktu terjadi peristiwa, maka nilai yang dipakai sebagai nilai benda asuransi adalah nilai penjualan, bukan nilai pembelian jika benda itu diperdagangkan. Jika benda asuransi itu benda untuk dipakai sendiri atau bukan benda perdagangan, maka yang dijadikan nilai benda asuransi adalah nilai tukarnya. Scheltema juga menekankan pada nilai penjualan jika benda asuransi itu benda perdagangan dan nilai penggantian atau nilai tukar (substitution price) jika benda asuransi itu benda yang dipakai sendiri. Dalam asuransi laut ada beberapa pasal yang mengatur nilai benda asuransi, yaitu Pasal 612, Pasal 613, dan Pasal 619 KUHD. Ketiga pasal tersebut merumuskan pengertian nilai benda suransi yang khusus digunakan dalam asuransi.

a. Pasal 612 KUHD, nilai benda asuransi adalah nilai benda yang diangkut ditambah biaya-biaya sampai di kapal pada waktu kapal berangkat dari pelabuhan embarkasi.

b. Pasal 613 KUHD, nilai benda asuransi adalah nilai benda sesungguhnya ditambah biaya angkutan, bea masuk, dan lain-lain apabila benda tersebut tiba dengan selamat di pelabuhan tujuan asalkan dicantumkan dalam polis. Akan tetapi, menurut pasal 614 KUHD biaya-biaya tambahan itu gugur (tidak mengikat jika benda tersebut tidak sampai di pelabuhan tujuan 


\section{Zurnal Negara dan $\mathcal{X}$ eadilan \\ p-ISSN 2302-7010 e-ISSN 2721-9801}

c. Pasal 619 KUHD, nilai benda asuransi adalah nilai badan kapal (hull) yang telah ditetapkan dalam polis. Akan tetapi, dapat diadakan penaksiran lagi jika menurut para ahli nilai badan kapal itu telah berkurang pada waktu terjadi peristiwa berdasarkan penetapan pengadilan.

Pada waktu mengadakan asuransi, pihak-pihak dapat melakukan penaksiran terhadap nilai benda asuransi. ${ }^{18}$ Nilai taksiran itu ditetapkan dalam polis. Jika terjadi peristiwa yang menimbulkan kerugian, maka nilai yang tercantum dalam polis itulah yang dijadikan dasar perhitungan ganti kerugian. Akan tetapi, mungkin juga bahwa taksiran nilai benda yang telah disepakati itu melebihi nilai sesungguhnya ketika memperhitungkan ganti kerugian setelah terjadi peristiwa. Apabila terjadi hal yang demikian ini, menurut Pasal 274 KUHD penanggung dapat mengajukan keberatan dengan mengemukakan alasanalasannya bahwa nilai benda asuransi terlalu tinggi. ${ }^{19}$

Hakim berwenang untuk memerintahkan tertanggung supaya membuktikan bahwa nilai benda yang dicantumkan dalam polis itu adalah benar dan layak. Dengan demikian, nilai taksiran yang telah ditetapkan dalam polis dianggap sebagai permulaan bukti tertulis. Menurut ketentuan Pasal 274 KUHD, tertanggung dapat diperintahkan oleh hakim untuk membuktikan bahwa nilai benda yang tercantum dalam polis adalah layak. Akan tetapi, dalam Pasal 273 KUHD di mana nilai benda asuransi tidak dicantumkan dalam polis, tertanggung harus memmbuktikan bahwa nilai benda yang dinyatakan itu adalah benar dan layak dengan menggunakan segala macam alat bukti. Hal ini dapat dilakukan apabila penanggung menyangkal nilai benda tersebut.

Berbeda dengan hukum asuransi Indonesia, hukum asuransi di Inggris mengenai taksiran pihak-pihak tentang nilai benda asuransi. Menurut ketentuan Pasal 274 KUHD, penanggung dapat membantah nilai benda yang telah ditetapkan dalm polis. Akan tetapi, menurut ketentuan Pasal 27 ayat (3) The Marine Insurance Act 1906, apabila pihak-pihak telah bersepakat tentang nilai benda asuransi dan telah dicantumkan dalam polis, maka nilai tersebut mengikat (conculsive). Penanggung tidak dapat membantahnya. Ketentuan Pasal 27 ayat (3) tersebut menyatakan: "Subject to the provsions of this act and in the absence of fraud, teh value fixed by the policy is, as between in the insurer and the assured, conclusive of the insurable value of the subject intended to be insured, whether the loss be total or partial".

Selain dari nilai benda yang ditaksir sendiri oleh pihak-pihak, ada lagi nilai benda yang ditaksir oleh para ahli yang ditunjuk oleh para pihak itu sendiri. Apabila nilai benda asuransi telah ditetapkan berdasarkan taksiran para ahli tersebut, maka menurut ketentuan Pasal $275 \mathrm{KUHD}^{20}$ penanggung tidak dapat membantahnya, kecuali jika ada penipuan dan hal ini harus dibuktikan oleh penanggung yang bersangkutan. Taksiran para ahli dilakukan pada waktu mengadakan asuransi dan dicantumkan dalam polis. Dalam praktik asuransi di Indonesia, taksiran para ahli itu tidak bersifat mutlak dan tidak lazim dijalankan. Hal ini dapat dimaklumi karena taksiran para ahli mengenai nilai benda asuransi sebelum diadakan asuransi dirasakan sebagai hambatan dan kelambatan yang sulit

18 Man Suparman, Sastar widjaja, 2012, Aspek-Aspek Hukum Asuransi Dan Surat Berharga, Bandung: PT. Alumni, Hlm 21.

${ }^{19}$ M. Isa Arif, 1987, Bidang Usaha Perasuransian, Jakarta: Pradnya Paramita, Hlm 50.

${ }^{20}$ Lihat Pasal 275 KUHD 


\section{$\mathcal{H}$ urnal Negara dan Keadilan \\ p-ISSN 2302-7010 e-ISSN 2721-9801}

diatasi, apalagi dalam persaingan dunia usaha perasuransian dewasa ini. Oleh sebab itu, taksiran pihak-pihak seperti diatur dalam pasal 274 KUHD dipakai sebagai aturan umum, sedangkan penaksir dan pihak penanggung adalah tenaga ahli. $^{21}$

Dalam Pasal 246 KUHD terdapat rumusan: "dengan nama penanggung mengikatkan diri kepada tertanggung dengan menerima premi”. Berdasarkan rumusan tersebut, dapat diketahui bahwa premi adalah salah satu unsur penting dalam asuransi karena merupakan kewajiban utama yang wajib dipenuhi oleh tertanggung kepada penanggung. Dalam hubungan hukum asuransi, penanggung menerima pengalihan risiko dari tertanggung dan tertanggung membayar sejumlah premi sebagai imbalannya. Apabila premi tidak dibayar, asuransi dapat dibatalkan atau setidak-tidaknya asuransi tidak berjalan. Premi harus dibayar lebih dahulu oleh tertanggung karena tertanggunglah pihak yang berkepentingan.

Sebagai perjanjian timbal balik, asuransi bersifat konsensual, artinya sejak terjadi kesepakatan timbullah kewajiban dan hak kedua belah pihak. Akan tetapi, asuransi baru berjalan jika kewajiban tertanggung membayar premi telah dipenuhi. Dengan kata lain, risiko atas benda beralih kepada penanggung sejak premi dibayar oleh tertanggung. Oleh karena itu, dapat dipahami bahwa ada tidaknya asuransi ditentukan oleh pembayaran premi. Premi merupakan kunci perjanjian ausransi.

Pada asuransi yang diadakan untuk jangka waktu tertentu, premi dibayar lebih dahulu pada saat asuransi diadakan. Pada asuransi yang diadakan untuk 1 (satu) perjalanan, premi dapat dibayar pada saat bahaya sudah mulai berjalan, misalnya pada kapal yang sudah berangkat (Pasal 603 KUHD). Akan tetapi, ada asuransi yang diadakan untuk jangka waktu panjang, misalnya asuransi jiwa, pembayaran premi dapat dilakukan secara periodik, yaitu setiap awal bulan. Pada asuransi yang demikian ini jika pada suatu periode tertentu premi belum dibayar, asuransi berhenti. Setelah premi periode yang tertunggak itu dibayar, asuransi berjalan lagi. Jika premi periode yang tertunggak itu dibayar, asuransi berjalan lagi. Jika premi tidak dibayar, mengakibatkan asuransi itu batal. Untuk mencegah terjadi pembatalan asuransi karena premi belum dibayar biasanya pihak-pihak mencantumkan klausula dalam polis yang menyatakan "premi harus dibayar di muka (pada waktu yang telah ditentukan). Jika premi tidak dibayar pada waktu yang telah ditentukan, asuransi tidak berjalan. Jika terjadi peristiwa yang menimbulkan kerugian, penanggung tidak berkewajiban membayar klaim tertanggung.

Berdasarkan uraian di atas, maka dapat dipahami bahwa premi asuransi merupakan syarat mutlak untuk menentukan perjanjian asuransi dilaksanakan atau tidak. Kriteria premi asuransi adalah sebagai berikut:

a. dalam bentuk sejumlah uang;

b. dibayar lebih dahulu oleh tertanggung;

c. sebagai imbalan pengalihan risiko;

d. dihitung berdasarkan persentase terhadap nilai risiko yang dialihkan.

Dalam praktik asuransi, penanggung biasanya sudah menentukan syarat umum pembayaran premi seperti yang ditetapkan dalam polis. Dalam polis

${ }^{21}$ Abdulkadir Muhammad, 2015, Op. Cit., Hlm 102-103. 


\section{Zurnal Negara dan $\mathcal{X}$ eadilan \\ p-ISSN 2302-7010 e-ISSN 2721-9801}

standar asuransi kebakaran Indonesia syarat umum pembayaran premi ditetapkan sebagai berikut:

1 Menyimpang dari Pasal 257 KUHD dan tanpa mengurangi ketentuan yang diatur pada ayat (2) di bawah ini, maka merupakan prasyarat dari tanggung jawab penanggung atas jaminan asuransi berdasarkan polis ini bahwa setiap premi terhutang harus sudah dibayar lunas dan secara nyata telah diterima seluruhnya oleh pihak penanggung

a. Jika jangka waktu pertanggungan tersebut 30 (tiga puluh) hari kalender atau lebih, maka pelunasan pembayaran premi harus dilakukan dalam tenggang waktu 30 (tiga puluh) hari kalender, dihitung dari tanggal mulai berlakunya polis

b. Jika jangka waktu pertanggungan tersebut kurang dari 30 (tiga puluh) hari kalender, pelunasan pembayaran premi harus dilakukan dalam tenggang waktu sesuai dengan jangka wkatu pertanggungan yang disebut dalam polis.

2 Apabila jumlah premi sebagaimana dimaksud di atas tidak dibayar sesuai dengan cara dalam jangka waktu yang ditetapkan pada ayat (1) tersebut di atas, polis ini batal dengan sendirinya terhitung mulai tanggal berakhirnya tenggang waktu tersebut dan penanggung dibebaskan dari semua tanggung jawab sejak tanggal dimaksud.

Penetapan tingkat premi asuransi harus didasarkan pada perhitungan analisis risiko yang sehat. ${ }^{22}$ Besarnya jumlah premi yang harus dibayar oleh tertanggung ditentukan berdasarkan penilaian risiko yang dipikul oleh penanggung. Dalam praktiknya penetapan besarnya jumlah premi itu diperjanjikan oleh tertanggung dan penanggung secara layak dan dicantumkan dalam polis. Besarnya jumlah premi dihitung sedemikian rupa, sehingga dengan penerimaan premi dari beberapa tertanggung, penanggung berkemampuan membayar klaim ganti kerugian kepada tertanggung yang terkena peristiwa yang menimbulkan kerugian. Dalam jumlah premi yang harus dibayar oleh tertanggung juga termasuk biaya yang berkenaan dengan pengadaan asuransi itu. Rincian yang dapat dikalkulasikan dalam jumlah premi adalah:

a) Jumlah persentase dari jumlah yang diasuransikan;

b) Jumlah biaya-biaya yang dikeluarkan oleh penanggung, misalnya biaya materai, biaya polis;

c) Kurtase untuk pialang jika asuransi diadakan melalui pialang;

d) Keuntungan bagi penanggung dan jumlah cadangan

Tingkat premi dinilai berlebihan apabila sedemikian tinggi, sehingga sangat tidak sebanding dengan manfaat yang diperjanjikan dalam polis asuransi yang bersangkutan. Penerapan tingkat premi dinilai bersifat diskriminatif apabila tertanggung dengan luas pengadaan yang sama serta dengan jenis dan tingkat risiko yang sama dikarenakan tingkat premi yang berbeda.

Premi asuransi dapat dibayarkan langsung oleh tertanggung kepada perusahaan asuransi atau melalui perusahaan pialang asuransi untuk kepentingan tertanggung. Dalam hal ini premi asuransi dibayarkan melalui perusahaan pialang asuransi, perusahaan ini wajib menyerahkan premi tersebut kepada perusahaan asuransi sebelum berakhir tenggang waktu pembayaran premi yang ditetapkan

5.

${ }^{22}$ Mulhadi, 2017, Dasar-Dasar Hukum Asuransi, Depok: PT. Rajagrafindo Persada, Hlm 


\section{Jurnal Negara dan $\mathcal{X}$ eadilan \\ p-ISSN 2302-7010 e-ISSN 2721-9801}

dalam polis asuransi yang bersangkutan. Dalam hal penyerahan premi oleh perusahaan pialang asuransi dilakukan setelah berakhirnya tenggang waktu tersebut. Perusahaan pialang asuransi yang berangkutan wajib bertanggung jawab atas pembayaran klaim yang timbul dari kerugian yang terjadi dalam jangka waktu antara habisnya tenggang waktu sampai diserahkannya premi kepada perusahaan asuransi.

\section{KESIMPULAN}

Menurut teori kepentingan (interest theory) pada benda asuransi melekat hak subjektif yang tidak berwujud. Kepentingan itu sifatnya absolut, artinya harus ada pada setiap objek asuransi dan mengikuti kemana saja benda asuransi itu berada. Kepentingan itu harus sudah ada pada benda asuransi pada saat asuransi diadakan atau setidak-tidaknya pada saat terjadi peristiwa yang menimbulkan kerugian (evenemen). Bagi tertanggung yang memiliki benda asuransi, kepentingannya melekat pada benda asuransinya.

Pada konteks perjanjian asuransi, maka dalam mencapai kepentingan berdasar keadilan dan kemanfaatan tidak dapat hanya berdasar keuntungan penanggung, melainkan kemanfaatan berupa kesempatan bagi pihak yang seharusnya bisa jadi tertanggung demi kesetaraan.

\section{DAFTAR PUSTAKA}

Abdulkadir Muhammad, 2006, Hukum Asuransi Indonesia, Bandung: Citra Aditya Bakti.

Davidson, Daniel, et al, 1997, Comprehensive Business Law, Principles and Cases, Kent Publishing Company, Boston, Massachusetts.

Djoko Prakoso, I Ketut Murtika, 1989, Hukum Asuransi Indonesia, Ctk. Kedua, PT. Bina Aksara, Jakarta.

Emmy Pangaribuan Simanjuntak, 1997, Beberapa Aspek Hukum Dagang di Indonesia, Jakarta: Bina Cipta.

Junaedy Ganie, 2013, Hukum Asuransi Indonesia, Ctk. Jakarta: Kedua, Sinar Grafika.

Kitab Undang-Undang Hukum Dagang

Man Suparman, Sastar widjaja, 2012, Aspek-Aspek Hukum Asuransi Dan Surat Berharga, Bandung: PT. Alumni.

M. Isa Arif, 1987, Bidang Usaha Perasuransian, Jakarta: Pradnya Paramita.

Mulhadi, 2017, Dasar-Dasar Hukum Asuransi, Depok: PT. Rajagrafindo Persada..

Purwosutjipto, 2003, Pengertian Pokok Hukum Dagang Indonesia, Jakarta: Djambatan.

Sri Redjeki Hartono, 1999, Hukum Asuransi dan Perusahaan Asuransi, Jakarta: Sinar Grafika.

The Marine Insurance Act 1906

UU No. 40 Tahun 2014 tentang Perasuransian. 